\title{
微動の水平上下スペクトル比のピーク周期の空間変動と 表層地盤の不整形性の関係

\author{
RELATIONSHIP BETWEEN IRREGULARITY OF SEDIMENT-BASEMENT INTERFACE AND \\ SPATIAL VARIATION IN PEAK PERIODS OF HORIZONTAL-TO-VERTICAL SPECTRAL RATIO \\ OF MICROTREMORS
}

\author{
元木 健太郎*, 渡 辺 哲 史*, 加藤 研一*, 武居 幸次郎**, \\ 山中浩明***, 飯場正紀****, 小山信*****
Kentaro MOTOKI, Tetsushi WATANABE, Kenichi KATO, Kojiro TAKESUE, Hiroaki YAMANAKA, Masanori IIBA and Shin KOYAMA

\begin{abstract}
We focused on spatial variation of horizontal to vertical spectral ratios (HVSRs) of microtremors as a proxy of an irregularity effect of sediment-basement interface. We perfomed 3 investigations: 1) we evaluated coefficents of variation (CVs) of HVSRs' peak periods at 4 sites based on densely mobile microtremor measurements, 2) evaluated sensitivity for CVs by numerical simulations for wave propagation with complex media, and 3) compared power spectral density estimated from CV s with that calculated from subsurface structure model. As a result, we found that $\mathrm{CV}$ s of peak periods were able to represent irregularities of sediment boundaries.
\end{abstract}

Keywords: Irregularity of geology, Microtremors, H/V peak period, Spatial variation, Variation coefficient, Power spectral density 地盤の不整形性，微動，H/V ピーク周期，空間変動，変動係数，パワースペクトル密度

\section{1.はじめに}

地盤の境界面に不整形がある場合、地震波の焦点効果により 1 次 元波動論による地盤増幅よりも振幅が大きくなる場合がある例えば1)。 2005 年福岡県西方沖地震の際、被害が集中した警固断層周辺で、表 層地盤の不整形性により増幅的干涉が発生したことが余震観測によ り確認されている2)。地盤の不整形性が予測される地域において地震 動増幅の評価精度を高めるには、直下の地盤構造のみならず境界面 の深さ分布も調べる必要がある。

地盤の不整形性を調べるためには、地下構造の線的または面的な 分布の推定が必要となる。不整形性を調べる評価手法として、多数 点での掘削調查例えば 3) や、複数の測線で表面波探査例えば4)、連続的な 微動アレイ測定例えば5) などが挙げられる。予め地盤の不整形性が予 測されている地域においては上記の評価が有効であるが、全ての㠻 イトで同様な評価を行うことは経済的な面から効率的とはいえない。 不整形性が小さい場合は 1 次元増幅率と大きく変わらない6)ことか
ら、詳細な調査の前に、地盤不整形性の有無を簡便に識別できれば、 地下構造探査の効率化が図れると考えられる。

簡便な地盤調查手法の一つとして単点微動があげられる。微動記 録の水平上下スペクトル比（以降、HVSR と呼ぶ）のピーク周期が 表層地盤の 1 次周期に近いことから、工学的基盤深さなどを推定す るために補完的に利用されることも多い例えば7。一様に傾いている層 境界面付近では、傾斜面に平行な水平方向の HVSR は、それと直交 する水平方向の HVSR よりも振幅が大きくなる特徵を有することが 報告されている ${ }^{8,9)}$ が、それらは片流れなどの比較的単純な形状周辺 の特徵を述べており、山地形の埋め立てなど複雑な基盤形状に対し ても同様な特徴を有するかまでは明らかにされていない。

HVSR が直下の地下構造を反映しているなら、多地点で計測した HVSR の変動により地盤の不整形性の大きさを表すことができる。不 整形な地盤において、HVSR に基づく地盤同定は、微動アレイ測定 よりも頑健であるという研究成果 ${ }^{10)}$ もある方で、地盤不整形性が

Kobori Research Complex Inc., Dr.Eng.

Kajima Corp.

Prof., Tokyo Institute of Technology, Dr.Eng

Prof., Hokkaido Univ., Dr.Eng.

National Institute for Land and Infrastructure Management, Dr.Eng. 
大きい場所付近では、推定誤差が大きくなることも報告されている例 えば11)。不整形性が大きい場所では、そこから発生する散乱実体波に より表面波の HVSR から乘離が生じることが指摘されており ${ }^{12) 、 そ ~}$ の乘離が推定誤差が大きくなる一つの要因と考えられる。そのよう な場合にも空間的に一様な HVSR になるとは考えにくく、HVSR に 空間的な変動は現れると推測される。HVSR の空間変動と地盤の不 整形性が関係するなら、HVSR が空間的に変動しているかを調心゙る ことによって、地盤の不整形性に関する情報が得られることになる。

そこで本論文では、HVSR のピーク周期（以降、ピーク周期と呼ぶ） の空間変動に着目し、地盤の不整形性の程度を表す指標になりうる かを検討した。両者の関係性を調べるために、以下の 3 つの項目を 検討した。まず、微動観測記録に基づき、不整形性があるサイトと 工学的基盤が平坦なサイトのピーク周期の空間変動の違いを調查し た。次に、数值解析に基づき、ピーク周期の空間变動に及ぼす地盤 モデルの影響パラメータを検討した。最後に、数值解析結果を用いて、 ピーク周期の空間変動を確率変数として捉え、地盤の不整形性との 関係性を論じた。

\section{2 ピーク周期の空間的変動の算出方法}

本論文では微動記録から地盤モデルを介さず、微動のピーク周期 の空間変動と地盤の不整形性の関係を調查する。空間変動の求め方 の概念図をFig.1 に示す。空間変動は、対象地点とある距離の周辺地 点で測定した微動ピーク周期の変動係数 CV (h)（=標準偏差／平均） によって表現する。

$$
C V(h)=\sqrt{\frac{1}{n_{h}} \sum_{j=1}^{n_{h}}\left(T\left(x_{j}\right)-\mu\right)^{2}}
$$

ここで、jはFig.1に示す中心と周辺の観測点、 $n_{h}$ は中心と半径 $h \pm$ $\Delta \mathrm{h}$ の範囲内にある観測点数、 $T\left(x_{j}\right)$ はピーク周期 /平均ピーク周期 を表す。 $\mu$ は平均ピーク周期を自分自身で基準化した值であるので、 1 となる。

3 章では微動の観測記録に、4 章では数值計算結果に (1) 式を適用 する。微動記録から HVSR を求める際は、より定常的な振動を抽 出するために、振幅の大きい非定常な部分を除外し、残った記録を 10.24 秒間のセグメントに分割した。記録や計算の各セグメントの フーリエスペクトルから HVSR を求め、それらの結果を平均化して 各観測点の HVSR とした。HVSRの細かい山谷によってピーク周期 の変動が左右されないように、平坦サイトの連続観測記録を用いて 対数型ウィンドウ ${ }^{14)}$ の幅を調整して、スムージングを施した。デー 夕処理方法の詳細は元木・他（2016）13)を参照されたい。

\section{3. 観測記録に基づくHVSR のピーク周期の変動 \\ 3. 1 対象サイトと微動測定概要}

地盤の不整形性の有無によるピーク周期の違いに焦点を当ててい るので、基盤が傾斜している地域と平坦な地域において微動測定し た。具体的には、元木・他（2016）13) で対象とした工学的基盤が平 坦な 2 サイト（大和・鶴見）に、工学的基盤が不整形性を有してい る 2 サイトを加えて、計 4 サイトを対象とする。追加したサイトの 工学的基盤の深度とピーク周期分布をFig.2、3 に示す。両サイトと も山地形を造成したサイトであり、Fig.2 中のハッチは法面を示す。
Fig.2 の名張サイトではM 52 地点でPS 検層を実施しており、元木・ 他 (2013） 5) にMWD 検層 ${ }^{3)}$ と PS 検層の比較が示されている。工学 的基盤の深さは MWD 検層 ${ }^{3)}$ によって求められた Np 值に基づいて いる。Np 值は標準貫入試験によって得られる $\mathrm{N}$ 值に相当する值を表

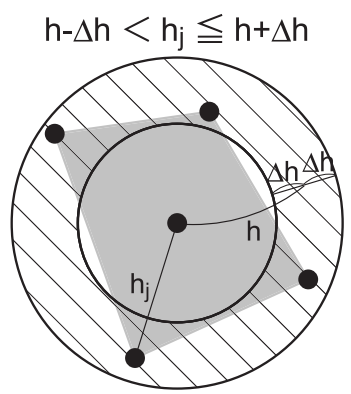

Fig. 1 Schematic image of area to evaluate coefficient of variation of peak periods.

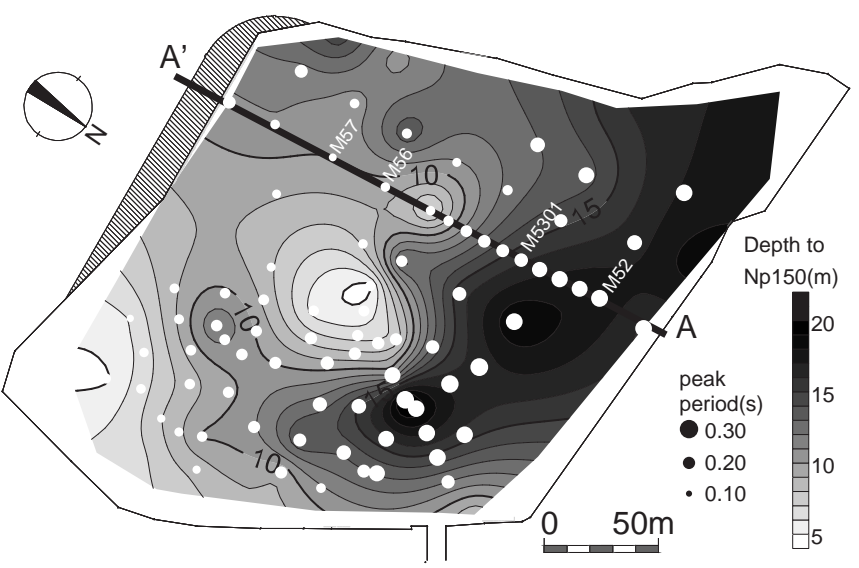

Fig. 2 Distribution of depth of Np150 measured with MWD method ${ }^{3)}$ and peak periods of HVSR at Nabari site.

(a)
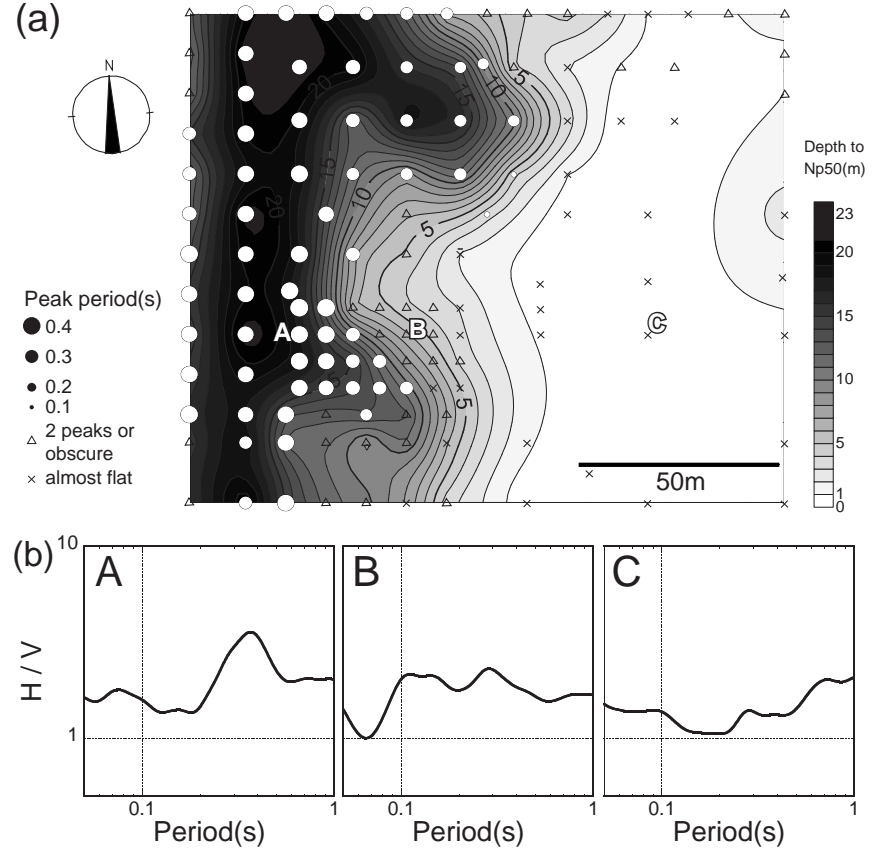

Fig.3 (a) Distribution of depth of Np50 measured with MWD method ${ }^{3)}$ and peak periods of HVSR at Kakegawa site and (b)samples of HVSR measured at A, B and C points shown in (a). 
(a)

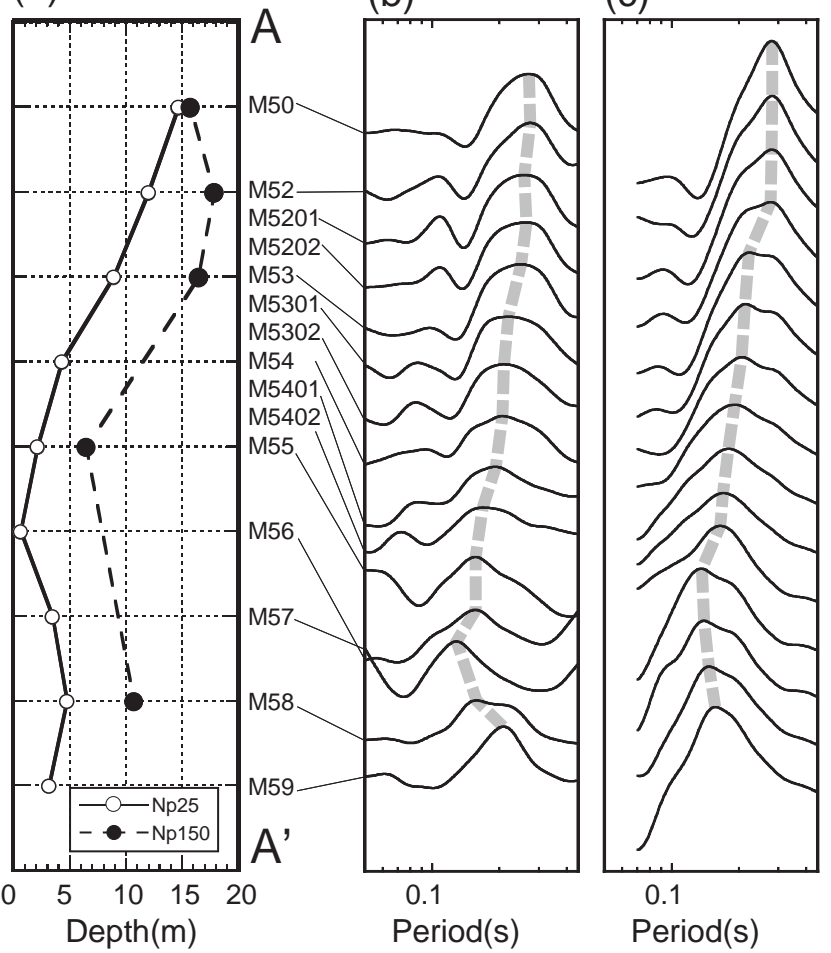

Fig. 4 (a) Depth of Np25 and Np150 and location of microtremor measurements at Nabari site shown in Fig. 1, (b) observed HVSR and transition peak periods shown with broken thick gray line, and (c) simulated HVSR and transition peak periods.

している31。名張サイトはPS 検層結果と照合し N p 值 150 が、掛川 サイトは標準貫入試験とのキャリブレーション結果から Np 值 50 が 工学的基盤に相当すると考えた。

微動測定は、MWD 検層 ${ }^{3)}$ やボーリングなどの掘削地点で測定し、 さらに不整形性が大きいと判断されたエリアに、補間的に配置した 点でも測定した。機器は旧 A kashi 製の加速度計 GPL-6A 3P を用い、 10 分間以上の微動を記録した。複数の機材を用いたものの、同時に は測定しておらず、必ずしもそれらの観測時刻は一致していない。 しかし、いずれの測定も平日の昼間時刻に行っており、微動の周期 特性は大きく変動していないと考えられる。

\section{2 観測記録に見られるピーク周期の変動係数}

Fig.2 に示寸 A-A '測線の微動 HVSR と層境界面深度の推移を Fig.4 に示す。Fig.4(a) はNp 值に基づく深さ分布を表し、Np 值 25 は表層 $V s=220 \mathrm{~m} / \mathrm{s}$ の下面深度、 $\mathrm{Np}$ 值 150 は工学的基盤の上面深度に対応寸 る 5)。Fig.4(b) は観測記録のHVSR を、Fig.4(c) は後述する微動シミュ レーション結果の HVSR を表す。HVSR の灰色破線はピーク周期の 推移を表す。Fig.4(b) においてM 52 など基盤面深度の変化が緩やかな 場所では HVSR は明膫なピークを示すが、基盤傾斜している M 5301 などでは、HVSR はピーク周期付近の振幅がなだらかな形状を示す。 新井・他（2011）15) や保井・他（2011）16) で報告されている不整形 地盤上での HVSR の形状の特徵と調和的であり、Fig.4(C)のシミュ レーション結果は記録ほじ顕著ではないが、上記の特徴を有してい る。ピーク周期付近がなだらかな形状に近い場合、ピーク周期付近

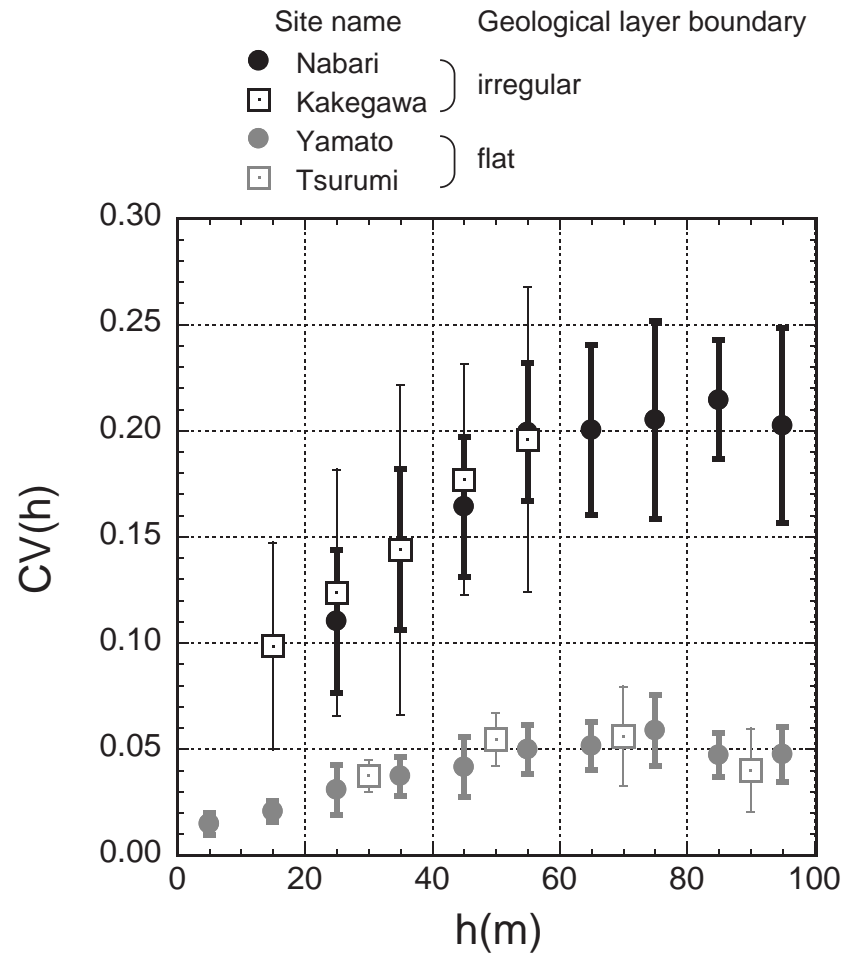

Fig. 5 Comparison of $\mathrm{CV}$ of peak periods at 4 sites. The lateral axis, $h(m)$ means interstation distances shown in Fig. 1. The black marks indicate the results at the irregular sites, and the gray ones indicate those at the flat sites.

にわずかな変化が現れるだけでピーク周期がシフトするため、その 観測点周辺ではピーク周期が変動しや寸くなる。事実、M 5301 付近 でピーク周期は変動している。M 56 やM 57 と基盤が浅くなるにつれ、 HVSR の形状が鋭くなり、ピーク周期は基盤が深い地点よりも短く なる。深い場所で周期が長く、浅い場所で周期が短くなり、層厚と 周期の関係は対応している。なお、シミュレーションの解析条件は 4 章にて記述する。

各評価点の HVSR のピーク周期の分布をFig.2 と Fig.3 に示す。大 局的にはFig.4 に示したように、基盤が深い場所で周期が長く、浅 い場所で周期が短い傾向を示している。名張サイトでは、全ての観 測点でピーク周期を確認することができた。掛川サイトでは、主に 工学的基盤が浅い東側の地域において、ピーク周期が判読できない 地点もあった。それはピークが複数ある場合や曖昧なもの、また短 周期の HVSR がほぼフラットな場合による。ピークが一つ (A)、複 数 (B)、山が小さくピークが判読できない (C) の 3 点を例として、 Fig.3(b) にそれらのHVSR を示す。HVSR がB 点やC 点の HVSR に 類似する観測点は、Fig.3(a) にそれぞれ $\triangle$ と $\times$ で示している。

各サイトのピーク周期を用いて、観測点間距離 $10 \mathrm{~m}$ （名張サイト、 掛川サイト、大和サイト）または $20 \mathrm{~m}$ （鶴見サイトのみ）ごとに変 動係数を求めた。距離範囲を変化させ、100m まで評価した変動係数 をFig.5 に示す。横軸の h は観測点間距離を表し、縦軸の CV (h) は変 動係数を表す。掛川サイトは、測定対象地域の南北長さが $122 \mathrm{~m}$ で あることと、東側の地域でピーク周期が求められなかったため、距 離が $60 \mathrm{~m}$ 以上の範囲はプロットしなかった。Fig.5 には、基盤形状が 不整形である名張サイトと掛川サイトを黒で、平坦な大和サイトと 


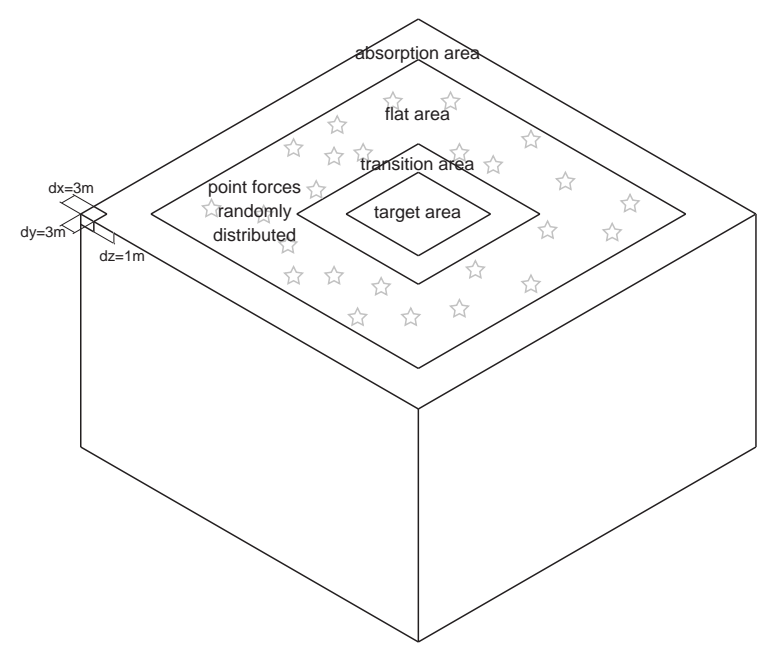

Fig. 6 Schematic image to construct subsurface structure models for numerical simulations.

Table 1 Soil physical propaties.

\begin{tabular}{|c|c|c|c|c|}
\hline $\begin{array}{l}\text { Layer } \\
\text { and } \\
\text { Material }\end{array}$ & $\begin{array}{c}V s \\
(\mathrm{~m} / \mathrm{s})\end{array}$ & $\begin{array}{c}V p \\
(\mathrm{~m} / \mathrm{s})\end{array}$ & $\begin{array}{l}\text { density } \\
(\mathrm{cm} / \mathrm{s})\end{array}$ & Q \\
\hline 1 & 220 & 1500 & 1.7 & \multirow{6}{*}{$10 \mathrm{f}^{1.0}$} \\
\hline 2 & 360 & 1900 & 1.8 & \\
\hline 3 & 460 & 2000 & 2 & \\
\hline$\alpha$ & 2200 & 3300 & 2.3 & \\
\hline $4 \bar{\beta}$ & 800 & 2200 & 2.1 & \\
\hline$\gamma$ & 1200 & 2600 & 2.2 & \\
\hline
\end{tabular}

Table 2 Parametric study cases of numerical simulations.

\begin{tabular}{cccccl}
\hline $\begin{array}{c}\text { model } \\
\text { name }\end{array}$ & $\begin{array}{c}\text { relative } \\
\text { slope } \\
\text { angle to } \\
\text { Model A }\end{array}$ & $\begin{array}{c}\text { average } \\
\text { depth of } \\
\text { layer } \\
\text { boundary } \\
\text { to Model } \\
\text { A }\end{array}$ & $\begin{array}{c}\text { relative } \\
\text { model } \\
\text { size to } \\
\text { Model A }\end{array}$ & $\begin{array}{c}\text { material } \\
\text { of the } \\
\text { deepest } \\
\text { layer } \\
\text { listed in } \\
\text { Table 2 }\end{array}$ & note \\
\hline Model A & 1 & 1 & 1 & $\alpha$ & basic model \\
Model B & $1^{*}$ & 1 & 1 & $\alpha$ & flat only on the deepest boundary \\
Model C & 0 & 1 & 1 & $\alpha$ & flat on all boundaries \\
Model D & 0.5 & 1 & 1 & $\alpha$ & half slop angles \\
Model E & 1.5 & 1 & 1 & $\alpha$ & 1.5 times the slope angles \\
Model F & 1 & 1.5 & 1.5 & $\alpha$ & 1.5 times the model size \\
Model G & 1 & 2 & 2 & $\alpha$ & 2 times the model size \\
Model H & 1 & 1 & 1 & $\beta$ & different material of the deepest layer \\
Model I & 1 & 1 & 1 & $\gamma$ & different material of the deepest layer \\
\hline
\end{tabular}

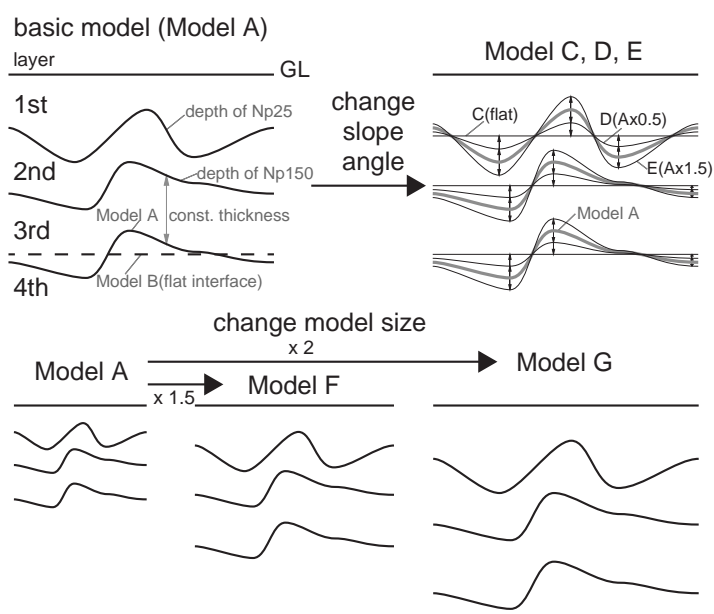

Fig. 7 Schematic image to construct Model A to G.
鶴見サイトを灰色で、変動係数の平均と標準偏差を示している。基 盤の不整形の有無によって、変動係数の值に明瞭な違いが認められ、 ピーク周期の空間変動への地盤不整形性の寄与は大きいといえる。 また、どの距離範囲でも平坦サイトと不整形サイトの值は \pm 10 を 考慮しても重ならないことから、地盤不整形性の程度を識別する指 標となる可能性を表している。

本論文の変動係数の評価には、ピーク周期が評価されている点を 対象としているが、上述したようにピーク周期が求まらない地点も ある。ピーク周期が求まらない場合は、ピーク周期から地盤境界面 の情報を得ることができず、本手法の対象外となる。ピーク周期が 求められない地点は、工学的基盤が露頭している地域のほかに、地 盤の速度コントラストが明瞭でない地域の可能性もあり、他の探査 手法による調査が望まれる。

\section{4. 数值解析に基づくピーク周期の変動係数に影響するパラメータ \\ 4. 1 数値計算の概要}

ピーク周期の空間変動に寄与する、地盤不整形を表すパラメータ を明らかにするため、不整形地盤モデルを用いた微動シミュレーショ ンを実施した。まず、シミュレーションによる観測記録の空間変動 の再現性を確認し、次に地盤モデルに関するパラメトリックスタディ を行った。

数值解析の対象は、全ての観測点でピーク周期が求められたこと と、PS 検層結果が得られていることから名張サイトとした。地盤モ デルと振動源の配置の概念図をFig.6 に示し、計算は 3 次元有限差分 法を用いた。グリッド間隔に関して、周期 0.07 秒まで計算できるよ うに、水平方向は $3 \mathrm{~m}$ とした。鉛直方向は、表層付近については地盤 の不整形性ができるだけ細かく表現できるよう $1 \mathrm{~m}$ と、最下層以深に ついては下限周期 0.07 秒と最下層 V s に基づき設定した。

Fig.6の中心に示す対象エリアは、Fig.2 の領域を含む範囲を表し、 層境界面は不整形な形状を設定している。加振点を配置している平 坦エリアは水平成層としており、各層の境界面深さは対象エリアの 平均值としている。不整形から水平成層へ推移するエリアは、 $100 \mathrm{~m}$ の幅を設けている。モデル境界に位置する吸収領域は 20 グリッドを 設定した。

地盤モデルは、名張サイトの実地盤を再現するように、PS 検層や MWD 検層 ${ }^{3)}$ に基づいて構築し、このモデルを基本モデルとした。地 盤の物性はPS 検層に基づき、各層の值を Table1 に示す。地盤減衰は $1 \mathrm{~Hz}$ で $5 \%$ となる減衰を与えた。表層付近のVsは場所によって異な ることも考えられるが、ここでは層境界の形状で地盤の不整形性を 表現する。ここで、ピーク周期に影響を与える層を考察する。本論 文では不整形地盤を対象としているので、正規モードが必ずしも支 配的になると限らないが、レイリー波の基本モードを確認すると第 1 層から第 4 層までを考慮した場合にはピークは見られるが、第 4 層 を除いた場合、明瞭なピーク周期は確認できなかった。実体波が卓 越した場合も速度コントラストの強い層境界のピーク周期に対する 寄与が大きいことから、第 1 層から第 4 層までの層構造がピーク周 期に寄与していると考えられる。層境界の不整形性は、第 1 層と第 2 層の境界面を Np 值 25 の深度と、第 2 層と第 3 層の境界面を Fig. 2 に 示寸 Np 值 150 の深度とした。第 3 層と第 4 層の境界面の分布に関す る情報が得られなかったため、第 3 層の厚さを一定とした基本モデ 
(a)

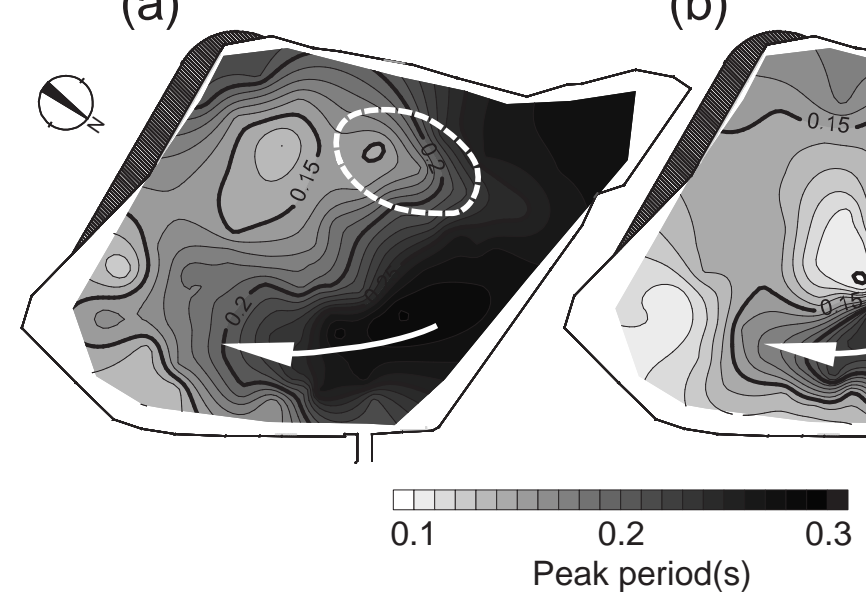

(c)

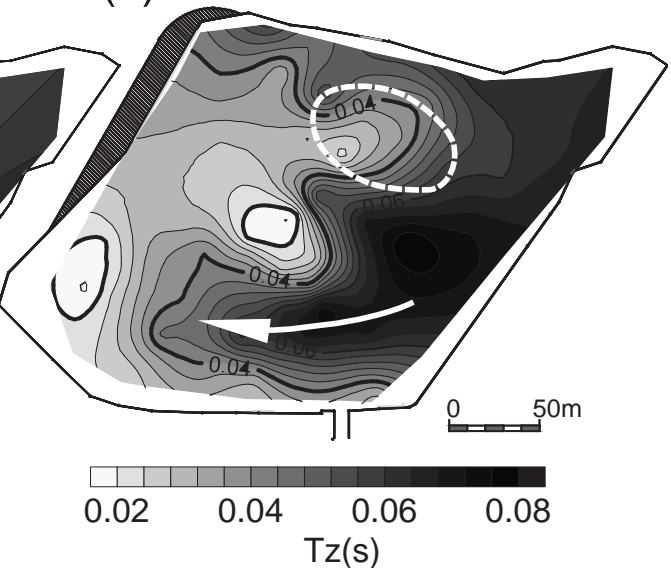

Fig. 8 (a) Distribution of observed peak periods, (b) peak periods simulated from Model A, and (c) Tz of Model A.

ル (Table 2 の M odel A) と、第 4 層の上面深度を一定としたモデル (Table 2 の M odel B）を設定した。各検層地点のデータから K riging 法 ${ }^{17)}$ 用いて面的な境界面深度の空間分布を推定した。なお、K riging 法に は後述のセミバリオグラムをモデル化した重み係数を用いている。

パラメトリックスタディのためのモデル化は、基本モデルから地 盤モデルのパラメータを変動させて設定した。上述したModel A, B を含め、設定したモデルをT Table 2 に示す。変動するパラメータは、 境界面の傾斜、モデルサイズ、最下層の物性值とした。基本モデル (M odel A) 、最下層上面を平坦とした M odel B、および境界面の傾斜 やモデルサイズを変動した M odel C G のモデル作成の概念図を Fig.7 に示す。M odel C G の第 3 層の厚さは基本モデルと同様に一定とし ている。境界面の傾斜を変動させたモデル（M odel C, D , E) は、各層 の境界面に対して深さ分布から求められる平均深さを固定し、平均 深さから各地点の深さの差を、0 倍 (平坦)、0.5 倍、1.5 倍し、定数 倍した差を平均深さに加えて、境界面深さ分布を設定した。モデル サイズを 1.5 倍、2.0 倍と変更したモデル (M odel F, G) では、グリッ ド間隔をそれぞれ 1.5 倍、2.0 倍と変更し、3 次元全ての方向に対し て比例的に拡大したモデルを設定した。振動源位置も比例的に離れ た配置となるが、振動源の時間関数に関しては、その他のモデルと 同じものを用いている。最下層の物性を変えたモデル (M odel H,I) は、 最下層と表層間の速度コントラストによるHVSR のの影響を調べる ため、最下層のVsを800,1200 と変更し、Vpもそれに合わせて変更 した。

振動源は全てのケースで同じ条件を与えている。振動源は地表点 における上下加振、加振点数は 25 地点とし、位置はランダム配置と している。振動源の時間関数は加速度スペクトルでホワイトとなる ように正規乱数を発生させたものを用い、各振動源で異なる乱数を 用いた。シミュレーションの継続時間は 160 秒間とした。

微動記録のピーク周期分布、基本モデル（Model A) 時のシミュレー ション結果のピーク周期分布、および地表から最下層上面までの鉛 直方向の $\mathrm{S}$ 波走時 $\mathrm{T} \mathrm{z}^{18)}$ の比較を Fig.8 に示す。地盤モデルの各層の 厚さが地盤周期に関係すると考え、地盤モデルの不整形性を表す量 として、佐藤・他 (2014) ${ }^{18)}$ で提案されているTzを採用した。Fig.8の 比較において、全体的な傾向として、北側で周期が長く（境界面が 深く）、南側で周期が短く（境界面が浅く）なる傾向や、Fig.8 中の矢

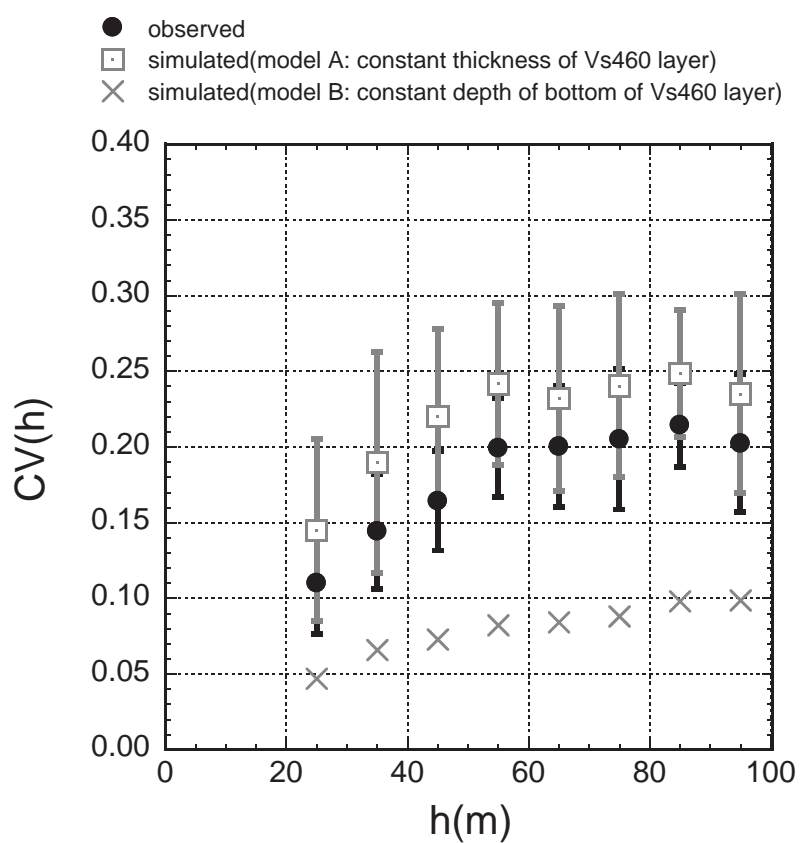

Fig. 9 Comparison of observed and simulated CVs of peak periods. The observed one is located between the results of Model A and $B$, and shows nearer the result of Model $A$ than that of Model B.

印で示寸東側の北から南に上がっていく谷形状は、それぞれ概ね対 応している。しかし、主に西側に見られる尾根状の形状（Fig.8 の破 線で囲まれている範囲）は3つの結果で対応していないなど、細か な部分には相違が見られた。

\section{2 数值計算と観測の比較}

微動シミュレーション結果のピーク周期から、Fig.5 と同様に距 離範囲ごとにピーク周期の変動係数を求めた。観測記録との比較を Fig.9 に示寸。シミュレーション結果には、基本モデルの Model A と 第 4 層の上面を水平にした M odel B の值を示している。観測記録の 結果と M odel A の結果は、 $55 \mathrm{~m}$ まで変動係数の值が大きくなり、 $55 \mathrm{~m}$ より長い範囲においてその傾きが小さくなる傾向はよく対応してい る。観測記録の変動係数の絶対值は、Model A と M odel B の間にあり、 
$\neg-$ original slope angle (model A)

$\checkmark$ flat(model C)

$\rightarrow$ half the slope angle (model D)

$\triangle-1.5$ times the slope angle(model E)

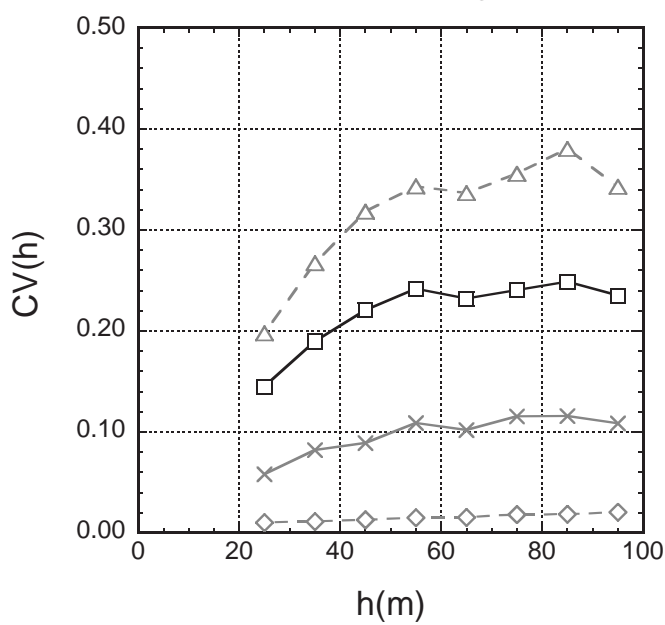

Fig. 10 Comparison of CVs simulated among models by various slope angles. These models were constructed keeping the average depths of boundaries and model sizes.

$\neg-$ original size (Model $A, X=1.0$ )

$\diamond 1.5$ times the model size (Model $F, X=1.5$ )

$\star 2.0$ times the model size (Model $G, X=2.0$ )

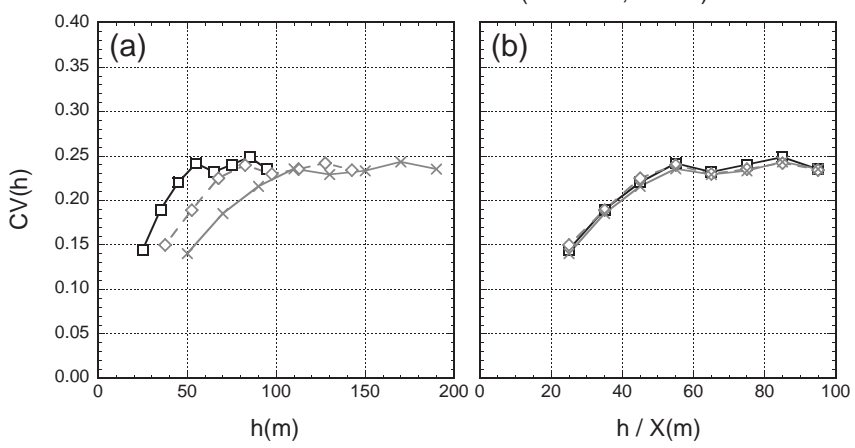

Fig.11 Comparison of CVs simulated among models by varing model sizes. The lateral axis in (a) is set to be interstation distances and that in (b) to be the distances devided by the size rates.

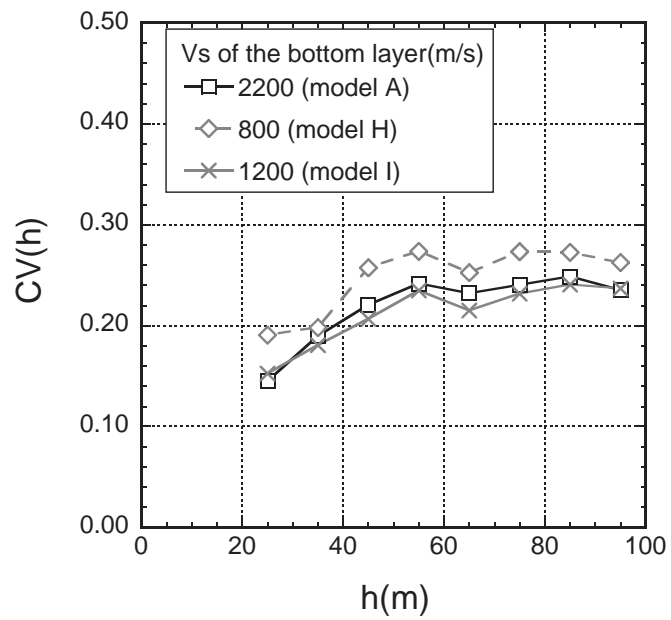

Fig. 12 Comparison of CVs simulated among models by various materials of the bottom layer.

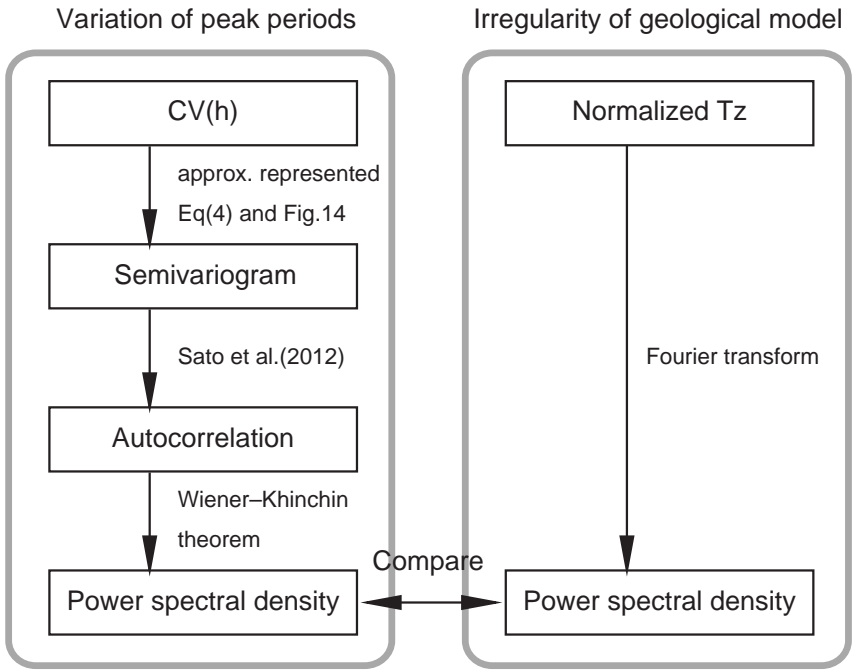

Fig. 13 Flow chart to compare a variation of peak periods directly with irregularity of a geological model.

Model A の結果に近い。

計算結果が観測記録と対応しない要因として、第 3 層と第 4 層の 境界面の深度分布に関する情報がないことと、表層のVs が場所に よって異なることなどが考えられる。境界面の深度分布に関して Fig.9 の結果から考えると、第 4 層の上面は水平上りも第 3 層の上面 の形状（第 3 層の厚さが一定）の方に近く、それよりもやや緩やか になっている形状と推定される。Model A の結果は観測記録よりも值 が大きいものの、変動係数の全体的な傾向は再現していることから、 以降の検討では、数值解析の結果を基に議論を展開する。

\section{3 基盤傾斜や深さに対する変動係数の感度}

パラメトリックスタディに基づいてピーク周期の変動係数に影響 するパラメータを整理する。まず、層境界面の傾斜を変動した M odel A，C，D，Eの結果をFig.10 に示す。各モデルの結果は全て、55m まで 変動係数が上昇し、55m より長い範囲で傾きが緩やかになる傾向は よく対応している。一方、絶対值が傾斜によって明瞭に異なっており、 変動係数の絶対值は層境界面の傾斜に対して感度が高いことを表し ている。全ての層境界面を平坦としたM odel C の結果は、約 $2 \%$ と Fig.5 に示す大和サイトや鶴見サイトなど観測記録よりも小さい。ま た大和サイトを対象にシミュレーションした結果（元木・他、2016 のFig.16）と比較しても小さいことから、地盤モデルの違いに起因し ていると考えられる。

次に、モデルサイズの異なる M odel A，F， G の結果の比較を Fig.11 に示す。左図は観測点間距離を横軸にとり、右図は観測点間距離を、 サイズ倍率で除した值を横軸にとっている。変動係数の絶対值はほ とんど同じであるが、傾きが緩やかになる折れ曲がりの距離が異なっ ている（Fig.11(a)）。サイズ倍率で割った距離でみると、各結果はほ ぼ重なる (Fig.11(b))。変動係数の傾きが小さくなる距離はサイズ倍 率に比例することから、不整形な境界面形状（以降、凹凸と呼ぶ） の水平方向の波長と関係すると考えられる。

最後に、地盤物性の影響を見るため、速度コントラストに変化を 与えたモデル M odel A， H，I の結果の比較をFig.12 に示す。Vs=800m/ $\mathrm{s}$ の時の結果が V $\mathrm{s}=1200,2200 \mathrm{~m} / \mathrm{s}$ 時よりもやや大きいが、その差は 


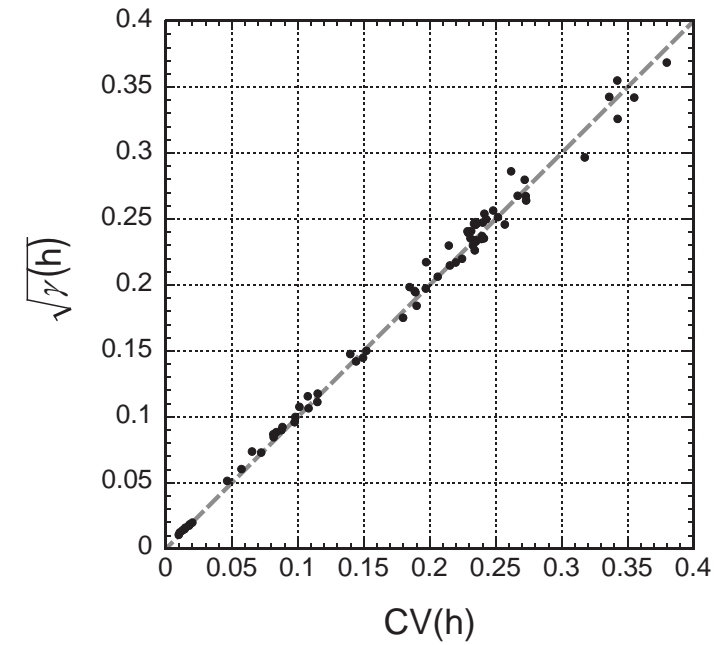

Fig. 14 Comparison between square root of semivariogram and CVs, which consist of simulated data of 9 cases.

Fig.10に示す地盤モデルの傾斜による差よりも顕著に小さい。従って、 地盤の速度コントラストが変動係数に及ぼす影響は、地盤の不整形 性による影響と比較して十分に小さく、考慮しなくても傾向は捉え られると考えられる。

以上の結果から、ピーク周期の変動係数の絶対值は地盤モデルの 層境界面の凹凸の振幅に、変動係数の傾きが変動する距離は層境界 面の凹凸の水平方向の波長に関係し、それらに比べ最下層の地盤物 性は変動係数にほとんど影響がないことを明らかにした。

\section{5. ピーク周期の変動係数と地盤の不整形性の比較}

5. 1 変動係数とパワースペクトル密度の関係

ピーク周期の空間変動を確率変数とみなし、地盤の不整形性との 関係を検討するために、Fig.13に示すように両者をパワースペクトル 密度に変換して直接的に比較する。ここでの検討には、3 章で行っ たシミュレーションの結果と地盤モデルを用いる。

まずピーク周期の変動係数から、ばらつきを表現するセミバリオ グラム 199)を介して、パワースペクトル密度に導く。

変動係数 CV (h) の平均は、次式で示される。

$$
\overline{\mathrm{CV}(\mathrm{h})}=\frac{1}{\mathrm{~N}} \sum_{\mathrm{i}=1}^{\mathrm{N}} \sqrt{\frac{1}{\mathrm{n}_{\mathrm{hi}}} \sum_{\mathrm{j}=1}^{\mathrm{n}_{\mathrm{ii}}}\left(\mathrm{T}\left(\mathrm{x}_{\mathrm{j}, \mathrm{i}}\right)-\mu_{\mathrm{i}}\right)^{2}}
$$

ここで、N は変動係数が求められた観測点数、i は Fig.1 に示す中 心観測点を表し、(1) 式から観測点数分を平均化したものを示してい る。

セミバリオグラム $\gamma(h)^{19)}$ も変動係数と等価になるように平均で除 した值を用いて、CV (h) と比較できるように整理すると、以下の式で 表現できる。

$$
\begin{aligned}
\gamma(\mathrm{h}) & =\frac{1}{2} \frac{1}{\mathrm{~N}_{\text {pair }}} \sum^{\mathrm{N}_{\text {pair }}}(\mathrm{T}(\mathrm{x}+\mathrm{h})-\mathrm{T}(\mathrm{x}))^{2} \\
& =\frac{1}{\mathrm{~N}_{\text {pair }}} \sum^{\mathrm{N}_{\text {pair }}}(\mathrm{T}(\mathrm{x})-\mu)^{2}
\end{aligned}
$$

ここで、 $\mathrm{N}_{\text {pair }}$ は距離 $\mathrm{h} \pm \Delta \mathrm{h}$ にある観測点ペア数を表す。(3) 式の導

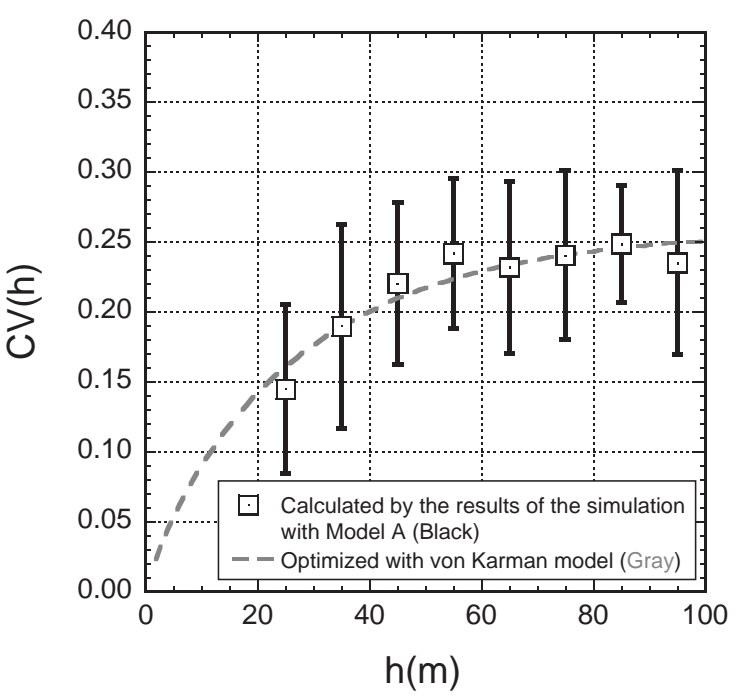

Fig. 15 CVs by simulated data from Model A, and square root of semivariogram with von Karman type of auto-correlation function using optimized parameters.

出は付録に示す。 $\mathrm{N}_{\text {pair }}$ は観測点数よりも多く、1つの観測点が複数回 カウントされることもあり、(2) 式でも複数回カウントされる観測点 がある。また (2) 式と (3) 式が表現する量は、それぞれ限られた距離 範囲にある点の標準偏差と分散であるから、両式は次式に示寸近似 の関係にあると考えられる。

$$
\sqrt{\gamma(\mathrm{h})} \cong \overline{\mathrm{CV}(\mathrm{h})}
$$

Table 2 に示す 9 ケースのシミュレーション結果を用いてセミバリ オグラムの平方根と変動係数を求め、その関係をFig.14 に示す。両 者はよく対応し、近似の関係にあることが確認できる。

セミバリオグラムは自己相関関数によって、次式で表現できる ${ }^{20)}$

$$
\begin{aligned}
& \gamma(\mathbf{h})=\frac{1}{2} \mathrm{E}\left[(\mathrm{T}(\mathbf{x}+\mathbf{h})-\mathrm{T}(\mathbf{x}))^{2}\right]=\mathrm{R}(0)-\mathrm{R}(\mathbf{h}) \\
& \mathrm{R}(\mathbf{h})=\mathrm{E}[\mathrm{T}(\mathbf{x}+\mathbf{h}) \mathrm{T}(\mathbf{x})]
\end{aligned}
$$

ここで、 $E[]$ は平均、R(h) は自己相関関数を表す。パワースペクト ル密度と自己相関関数はフーリエ変換対にある。

$$
\begin{aligned}
& P(\mathbf{k})=\iint \mathrm{R}(\mathbf{x}) \mathrm{e}^{-\mathbf{i k x}} \mathrm{d} \mathbf{k} \\
& \mathrm{R}(\mathbf{x})=\frac{1}{(2 \pi)^{2}} \iint P(\mathbf{k}) \mathrm{e}^{\mathrm{ikx}} \mathrm{d} \mathbf{x}
\end{aligned}
$$

ここで、 $\mathrm{P}(\mathrm{k})$ はパワースペクトル密度、k は波数を表す。パワース ペクトル密度は、変動係数から近似的に求められることが確認でき た。

\section{2 変動係数が有する地盤の不整形性の情報}

ピーク周期と比較する地盤モデルの不整形性に関する变数は、周 期と関係する量が望ましく、ここでは前述のTzとした。シミュレー ション結果を用いて、ピーク周期と Tz のパワースペクトル密度を比 較する。(8) 式を用いて積分できるようにピーク周期の変動係数を、 関数形で表現された自己相関関数を用いて近似する。ここでは、自 


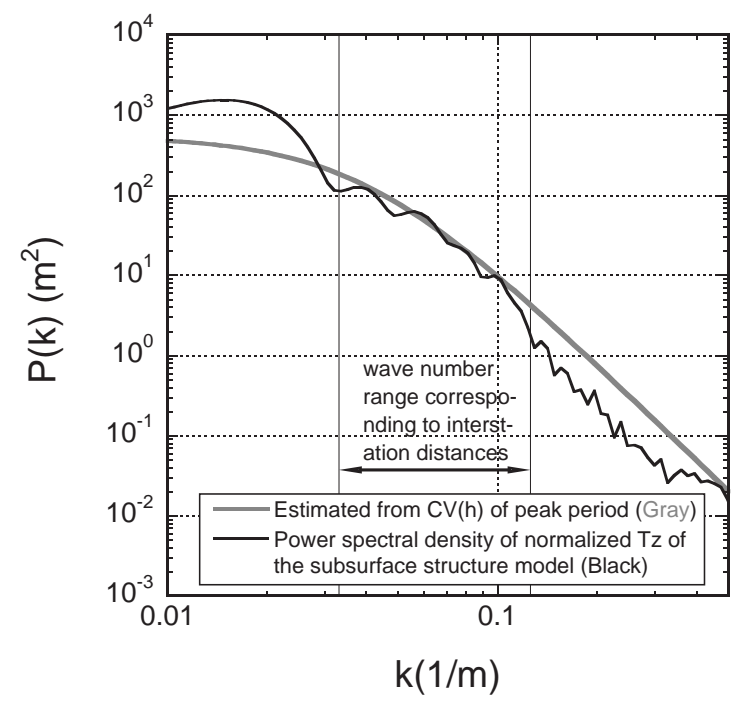

Fig. 16 Comparison of power spectral density functions between normalized Tz of Model A and estimated one by optimized parameters with $\mathrm{CV}$ s of peak periods.

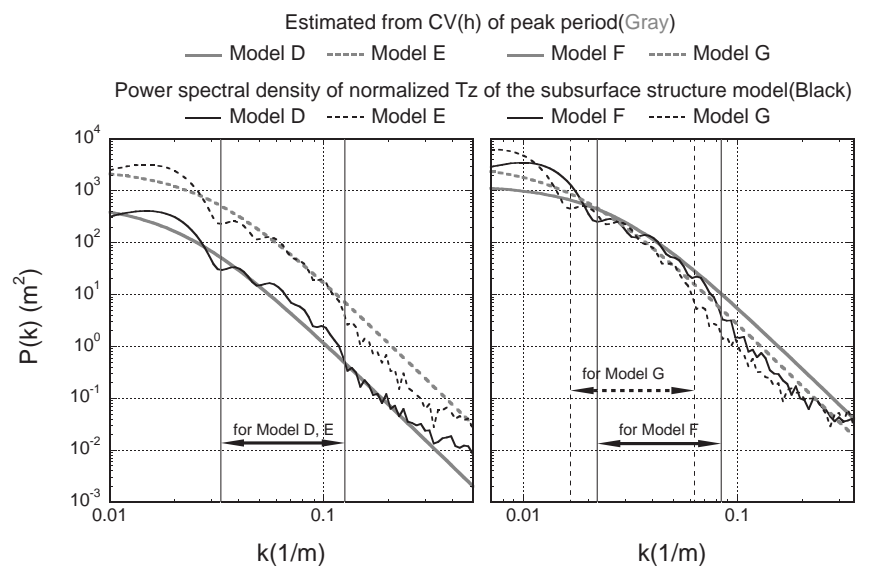

Fig. 17 Comparison of power spectral densities between normalized $\mathrm{Tz}$ and estimated by CVs. Left figure shows results by various slope angles and right one does those by various model sizes.

己相関関数の関数形としてフォンカルマン型 ${ }^{201}$ を採用する。

$$
\mathrm{R}(\mathrm{x})=\frac{\varepsilon^{2} 2^{1-\kappa}}{\Gamma(\kappa)}\left(\frac{\mathrm{x}}{\mathrm{a}}\right)^{\kappa} \mathrm{K}_{\kappa}\left(\frac{\mathrm{x}}{\mathrm{a}}\right)
$$

ここで、 $\varepsilon$ は摇らぎ、 $\kappa$ はハースト指数 $(0<\kappa \leqq 1) 、 \Gamma$ はガ ンマ関数、 $K \kappa$ は第 2 種 $\kappa$ 次変形ベッセル関数、aは相関距離を表す。 ガンマ関数と第 2 種変形ベッセル関数のソースコードはSLATEC の ライブラリ ${ }^{211}$ を参照した。関数のパラメータについて、๙がセミバ

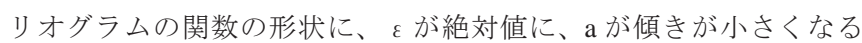
距離に関係する。グリッドサーチで、モデルとデータの差の L 1 ノル ムを最小とする各パラメータを求めた。Model A 時のピーク周期の 変動係数とそれに適合するセミバリオグラムの平方根を Fig.15 示す。 各パラメータは $\varepsilon=0.2576 、 a=25.5 、 \kappa=1.0$ と求められた。(9) 式を(7) 式に代入後に積分してパワースペクトル密度を求めると、2 次元の場 合は次式になる ${ }^{20)}$ 。

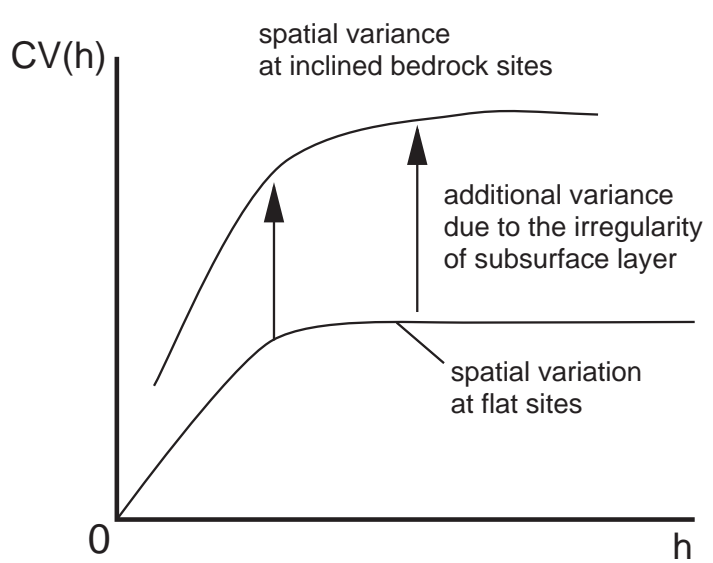

Fig. 18 Schematic image in the difference of $\mathrm{CVs}$ of peak periods.

$$
P(\mathrm{k})=\frac{4 \pi \Gamma(\kappa+1) \varepsilon^{2} a^{2}}{\Gamma(\kappa)\left(1+\mathrm{a}^{2} k^{2}\right)^{\kappa+1}}
$$

Tz のパワースペクトル密度は、ピーク周期の変動係数と等価にな るように次式でTz'に基準化し、Tz' を 2 次元フーリエ変換して求めた。

$$
T z^{\prime}=\frac{T z-E[T z]}{E[T z]}
$$

ここで、 $E[]$ は平均を表す。ピーク周期の変動係数に基づく (10) 式 による推定值と、M odel A のTz'のパワースペクトル密度の比較を Fig.16に示す。また、Fig.16 には観測点間距離の 2 倍を波長とした時 に対応寸る波数範囲を示している。その波数範囲において、ピーク 周期の変動係数からの推定值と $\mathrm{Tz}$ の值はよく対応している。

基本モデル時と同様に、傾斜を変更した地盤モデル（M odel D,E）と、 モデルサイズを変更した地盤モデル（Model F, G）に対して、ピーク 周期の変動係数と地盤モデルの Tz' を波数領域で評価し、その比較を Fig.17 に示す。全てのモデルにおいて、ピーク周期の変動係数から推 定した結果はTz' とよく対応している。両者が対応することは、不整 形地盤上のピーク周期と地盤モデルの凹凸の程度が類似しているこ とを表している。

上記の知見と元木・他 (2016) ${ }^{13)}$ での結果から得られる、ピーク 周期の変動係数と観測点間距離の関係の概念図をFig.18 に示す。不 整形性が 0、つまり層境界面が平坦である場合に変動係数は 0 とはな らず、観測点と振動源の距離関係によって $5 \%$ 程度の值を持つことが 確認されている ${ }^{13)}$ 。不整形がある場合、ここでのケーススタディの 結果（Fig. 16, 17）において、パワースペクトル密度でよく対応寸る ことから、ピーク周期の変動係数には、地盤の不整形性が寄与して いると考えられる。ピーク周期の変動係数は、境界面の傾斜に対し て感度が高いことと、不整形性の有無によって観測記録の結果が顕 著に異なることから、ピーク周期の変動係数の大きさによって、地 盤の不整形性を考慮しなければならないサイトか、水平成層構造で 近似できるかを識別ができる可能性がある。それは、例えば表層地 盤の基盤傾斜の調查が求められている限界耐力計算法の促進などに つながると考えている。地盤の不整形性を考慮す心゙きか否かの識別 に関して、具体的な方法や基準については、今後の検討課題としたい。 


\section{6. まとめ}

地盤の不整形性の有無を判断するための指標を検討するために、 単点微動の HVSR のピーク周期の空間的な変動に着目した。4 サイ トの微動測定、不整形地盤モデルを用いた微動シミュレーション、 およびピーク周期の空間変動と地盤モデルの不整形性の比較から以 下の知見を得た。

1. 微動観測記録に基づくピーク周期の変動係数は、工学的基盤が 平坦なサイトと不整形地盤のサイトでも、距離に応じて増加し、 ある距離から傾きが小さくなる傾向が見られた。ピーク周期の 変動係数の絶対值は、地盤の不整形性の有無によって大きく異 なり、 $\pm 1 \sigma$ を考慮しても両者は重ならなかった。

2. 不整形地盤モデルを用いた数值解析に基づき、ピーク周期の変 動係数の絶対值は地盤モデルの層境界面の傾斜に、変動係数の 傾きが小さくなる距離は地盤モデルのサイズ（層境界面の形状 の波長）に影響していることを確認した。

3. セミバリオグラムを介して、変動係数が近似的にパワースペク トル密度を表現できることを示した。ピーク周期の変動係数か ら推定したパワースペクトル密度は、地盤モデルのパワースペ クトル密度とよく対応し、ピーク周期の変動は地盤の不整形性 を表していることを示した。

以上の結果から、ピーク周期の変動係数は、地盤不整形性の程度 を表し、水平成層構造で近似できるかどうかの判断指標になりうる と考えられる。具体的な手順については、不整形性が与える地盤増 幅への影響も考慮しながら、今後整理したいと考えている。

\section{謝辞}

計測サイトの場所は藤森工業株式会社三重事業所とタイコエレク トロニクス合同会社から提供して下さいました。本研究は、国土交 通省が実施した平成 22、23 年度の建築基準整備促進事業による成果 の一部をフォローアップしたものです。測定作業は、東京工業大学 総合理工学研究科山中研究室の津野靖士博士（現鉄道総合技術研究 所)、大学生、大学院生に手伝っていただきました。また本研究の開 始時から、故三浦賢治博士に議論して頂きました。記してご協力く ださった関係各位に謝意を表します。

\section{参考文献}

1) Ohori, M., K. Koketsu, and T. M inami, Seismic Responses of Three Dimensionally Sediment-Filled Vallyes due to Incident Plane Waves, J. Phys. Earth, Vol. 40, pp.209-222, 1992

2) 元木健太郎・山中浩明・瀬尾和大・川瀬博 : 2005 年福岡県西方沖の地震の 余震観測に基づく警固断層周辺の不整形地盤による地盤特性の評価、日本 建築学会構造系論文集、第 602 号、pp.129-136、2006.4

3）西謙二・笹尾光・鈴木康嗣・武居幸次郎・實松俊明：回転打撃式ドリルを用 いた新しい地盤調査法、日本建築学会技術報告集、第 5 号、pp.69-73、1997

4) 林宏一・鈴木晴彦・斎藤秀樹：人口震源を用いた表面波探査の開発とその土 木調査への適用、応用地質技術年報、No.21、pp.9-39、2001

5) 元木健太郎・渡辺哲史 ·加藤研一 - 武居幸次郎・山中浩明・飯場正紀・小山信 : 微動アレイ計測に基づく傾斜基盤構造の推定、日本建築学会構造系論文集、 第 78 巻、第 688 号、pp.1081-1088、2013.6

6) 渡辺哲史・加藤研一・飯場正紀・小鹿紀英 : 工学的基盤の傾斜が表層地盤増 幅特性に与える影響に関する基本的検討、日本建築学会技術報告集、第 36 号、pp.455-458、2011.6

7) 浅野公之・岩田知孝・岩城麻子・栗山雅之・鈴木亘 : 地震および微動観測に よる石川県鳳珠郡穴水町における地盤震動特性、地震、第 2 輯、第 62 巻、 pp.121-135、2009
8) M atsushima, S., T. Hirokawa, F. D. M artin, H. Kawase, and F. J. Sánchez-Sesma, The Effect of $L$ ateral Heterogeneity on Horizontal-to-Vertical Spectral Ratio of M icrotremors Inferred from Observation and Synthetics, BSSA, Vol.104, N 0.1, pp.381-393, 2014.2

9) U ebayashi, H., H. Kawabe and K. Kamae: Reproduction of microseism H/V spectral features using a three-dimensional complex topographical model of the sediment-bedrock interface in the Osaka sedimentary basin, Geophysical J ournal International, Vol. 189, Issue 2, pp. 1060-1074, 2012.5

10) 上林宏敏・川辺秀憲・釜江克宏・宮腰研・堀家正則 : 傾斜基盤構造推定に おける微動 H/N スペクトルの頑健性とそれを用いた大阪平野南部域の盆 地構造モデルの改良、日本建築学会構造系論文集、第 74 巻、第 642 号、 pp.1453-1460、2009.8

11) 新井洋・上林宏敏 : 大阪堆積盆地における水平成層仮定の H N スペクト ル逆解析による基盤深度の推定誤差、日本建築学会大会学術講演梗概集、 B-2、pp.207-208、2013.8

12) 中川博人・中井正一 : 斜面地盤が短周期微動の H $/ \mathrm{V}$ スペクトルと分散曲線 に与える影響、日本建築学会構造系論文集、第 75 巻、第 656 号、pp.18271835、2010.10

13）元木健太郎・渡辺哲史 ·加藤研一・武居幸次郎・山中浩明・飯場正紀・小山信 : 微動の水平上下スペクトル比のピーク周期に見られる時間および空間変動 一工学的基盤が平坦なサイトにおける観測事例とその解釈一、日本建築学 会構造系論文集、第 81 巻、第 721 号、pp.437-445、2016.3

14) 紺野克明・大町達夫 : 常時微動の水平 /上下スペクトル比を用いる増幅倍 率の推定に適した平滑化とその適用例、土木学会論文集、N $0.525 / \mathrm{I}-33$ 、 pp.247-259、1995

15) 新井洋 : 埋没谷状の不整形地盤を有寸る造成宅地の微動特性に関寸る一検 討、日本建築学会大会学術講演梗概集、B-2、pp.151-152、2011.8

16) 保井美敏・成田修英・山本健史：常時微動による傾斜基盤地の H/N スペ クトルと地盤応答特性に関する検討、日本建築学会大会学術講演梗概集、 B-2、pp.145-146、2011.8

17) Cressie, N., Statistics for Spatial Data (Revised Edition), 1993

18) 佐藤智美・大川出・佐藤俊明・藤堂正喜・西川孝夫 : サイト固有の特性を 反映した経験式に基づく南海トラフ沿いの巨大地震に対する長周期地震動 予測、日本建築学会構造系論文集、第 79 巻、第 695 号、pp37-46、2014.1

19) Davis, J. C., A aalysis of Sequences of Data, Statics and Data A nalysis in Geology, pp.159-292, 2002

20) Sato, H., and M. C. Fehler, and Takuto M aeda, 2.3.2 M athmatical Description of Random M edia, Seismic Wave Propagation and Scattering in the Heterogeneous Earth, Springer, pp.19-27, 2012

21) SLATEC Common M athematical Library, http://www.netlib.org/slatec/, 2015.11.6 参照

付録 セミバリオグラムと変動係数の近似式に係る式の導出 本文のセミバリオグラムと変動係数を関連付ける(3) 式の導出を以下に示す。

$$
\begin{aligned}
\gamma(\mathrm{h}) & =\frac{1}{2} \frac{1}{\mathrm{~N}_{\text {pair }}} \sum^{\mathrm{N}_{\text {parr }}}(\mathrm{T}(\mathrm{x}+\mathrm{h})-\mathrm{T}(\mathrm{x}))^{2} \\
& =\frac{1}{2} \frac{1}{\mathrm{~N}_{\text {pair }}} \sum^{\mathrm{N}_{\text {par }}}\{(\mathrm{T}(\mathrm{x}+\mathrm{h})-\mu)-(\mathrm{T}(\mathrm{x})-\mu)\}^{2} \\
& =\frac{1}{2} \frac{1}{\mathrm{~N}_{\text {pair }}} \sum^{\mathrm{N}_{\text {pair }}}\left\{(\mathrm{T}(\mathrm{x}+\mathrm{h})-\mu)^{2}-2(\mathrm{~T}(\mathrm{x}+\mathrm{h})-\mu)(\mathrm{T}(\mathrm{x})-\mu)+(\mathrm{T}(\mathrm{x})-\mu)^{2}\right\} \\
& =\frac{1}{2}\left\{\frac{1}{\mathrm{~N}_{\text {pair }}} \sum^{\mathrm{N}_{\text {par }}}(\mathrm{T}(\mathrm{x}+\mathrm{h})-\mu)^{2}+\frac{1}{\mathrm{~N}_{\text {pair }}} \sum^{\mathrm{N}_{\text {par }}}(\mathrm{T}(\mathrm{x})-\mu)^{2}\right\} \\
& =\frac{1}{\mathrm{~N}_{\text {pair }}} \sum^{\mathrm{N}_{\text {parr }}}(\mathrm{T}(\mathrm{x})-\mu)^{2}
\end{aligned}
$$

ここで、 $\mathrm{x}+\mathrm{h}$ は $\mathrm{x}$ から $\mathrm{h} \pm \Delta \mathrm{h}$ の距離範囲にある位置を、 $\mathrm{T}(\mathrm{x}+\mathrm{h}) 、 \mathrm{~T}(\mathrm{x})$ はそ れらの位置のピーク周期の平均に対する比を表す。 $T(x+h) 、 T(x)$ の母集団は同 じで両者を入れ替えることも可能であり、任意である。 $\mu$ は $\mathrm{T}(\mathrm{x}+\mathrm{h}) 、 \mathrm{~T}(\mathrm{x})$ の 平均を表し、(A-1) 式の 3 行目第 2 項は $T(x+h)$ と $T(x)$ の共分散を表している。 $T(x+h)$ と $T(x)$ は同じ母集団かつ任意であるため無相関になり、共分散の值は 0 となる。また、 $T(x+h)$ と $T(x)$ は入れ替えられるから、4 行目の式は 5 行目の式 にまとめられ、本文の (3) 式が導出される。なお、本論文では時間的変動係数 にも使用していること、および使用頻度が高い表現であることから、変動係数 を採用した。 


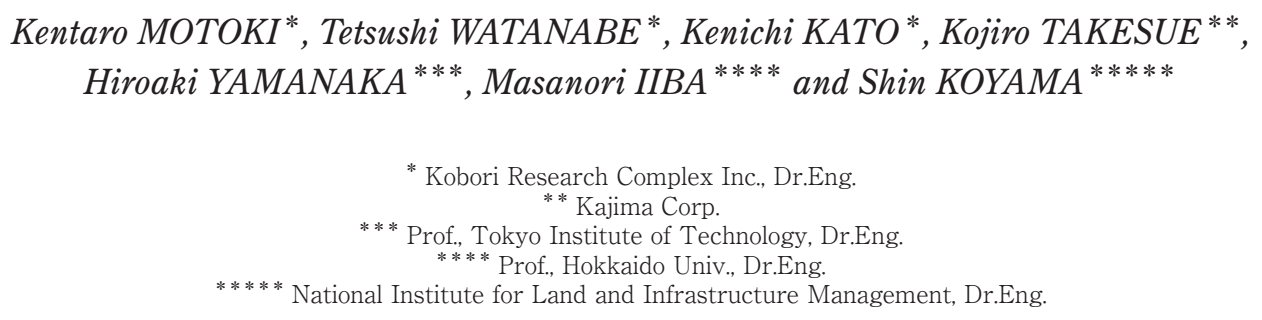

An irregularly layered subsurface structure (hereafter irregular site) amplifies earthquake motions sometimes more than a stratified media (hereafter flat site) due to, for example, a focusing effect of seismic waves. An exploration of a depth distribution of a structural boundary is too costly at each site in practice. A preliminary examination is desirable to discriminate sites where an amplification factor can be approximately estimated with stratified media from irregular sites. Focusing on spatial variation of horizontal to vertical spectral ratios (hereafter HVSRs) of microtremors, we performed 3 investigations with respect to a relationship between coefficients of variation of HVSRs' peak periods (hereafter CVs) and effects of irregular interfaces of a subsurface structure.

First, we conducted densely mobile microtremor measurements at 4 sites, which consist of 2 irregular sites and 2 flat sites. The values of CVs on the irregular sites are significantly larger than those on the flat sites, and they can be obviously separated.

Second, in order to reveal the characteristics of shapes of sediment interfaces affected the values of CVs, we analyzed sensitivity to CVs by numerical simulations for wave propagation with complex media. The basic subsurface structure model was constructed based on results of the drilling method at Nabari site where mobile microtremor measurements were also conducted. CVs of simulated motions with the basic model are almost consistent with the CVs by the observation. We found that slope angles and wave number of irregular boundaries of layers respectively affected amplitudes of CVs and inflection distances making a smaller inclination of CVs.

Third, we compared CVs with irregularity of subsurface structure, using results of simulated microtremors and subsurface structure models. For a comparison, we converted CVs to a power spectral density (hereafter PSD) via a semivariogram. The PSD estimated from CVs showed a good agreement with the PSD calculated from the subsurface structure model in the wave number range corresponding to interstation distances of the CVs.

Through the above investigations regarding the difference of CVs of irregular and flat sites, we concluded that CVs can be a proxy to represent an irregularity effect of sediment interfaces. 